\title{
ETNOGRAFIAS DA DURAÇÃO E OS DESEJOS DE MEMÓRIA FERROVIÁRIA NO SUL DO BRASIL
}

\author{
Guillermo Stefano Rosa Gómez (D)
}

Yuri Schönardie Rapkiewicz $ه$

Universidade Federal do Rio Grande do Sul I Porto Alegre - RS - Brasil

Cornelia Eckert $ه$

Universidade Federal do Rio Grande do Sul I Porto Alegre - RS - Brasil 


\section{RESUMO}

Neste artigo, buscamos estabelecer diálogo e convergência imagética entre etnografias da duração realizadas com comunidades de trabalho ferroviário em distintos contextos do Sul do Brasil. Tomando como categorias fundamentais a memória coletiva, a crise, a ruína, a cidade e o trabalho, queremos indicar a pluralidade e a complexidade das situações do patrimônio ferroviário no contexto da desativação das ferrovias brasileiras. Escolhemos como aspecto interpretativo central os desejos de memória dos ferroviários aposentados, indicando o caráter político cotidiano que a memória coletiva assume nos mais variados projetos de rememorar. Ressaltamos a pertença à nossa comunidade interpretativa, bem como a importância de, enquanto antropólogos(as) visuais, reconhecer, impulsionar e se aliar aos projetos êmicos de duração dos trabalhadores das cidades contemporâneas.

Palavras-chave: antropologia visual e da imagem; etnografia da duração; memória coletiva; trabalho ferroviário.

\section{ETHNOGRAPHIES OF DURATION AND THE WISHES OF RAILWAY MEMORY IN SOUTHERN OF BRAZIL}

\section{ABSTRACT}

In this paper, we propose a dialogue and imaging convergence between ethnographies of the duration carried out with railway work communities in different contexts of Southern Brazil. Taking as fundamental categories the collective memory, the crisis, the ruin, the city and the work, we indicate the plurality and complexity of railway heritage situations in the context of the deactivation of Brazilian railroads. We choose as central interpretative aspect the "wishes of memory" of the retired railway workers, indicating the daily political character that collective memory assumes in several remember projects. We emphasize belonging to our interpretative community, as well as the importance of as visual anthropologists to recognize, promote and ally with the emic projects of duration of the workers of contemporary cities.

Keywords: visual anthropology and anthropology of image; ethnography of duration: collective memory; railway work.

\section{ETNOGRAFÍAS DE LA DURACIÓN Y LOS DESEOS DE MEMORIA FERROVIARIA EN EL SUR DE BRASIL}

\section{RESUMEN}

En este artículo buscamos establecer un diálogo y una convergencia imaginetica entre etnografías de la duración realizadas con comunidades de trabajo ferroviario en distintos contextos del Sur de Brasil. Tomando como categorías fundamentales la memoria colectiva, la crisis y la ruina, la ciudad y el trabajo, buscamos indicar la pluralidad y complejidad de las situaciones del patrimonio ferroviario en el contexto de desactivación de las ferrovías brasileñas. Escogemos como aspecto interpretativo central los deseos de memoria de los ferroviarios jubilados, indicando el carácter político cotidiano que la memoria colectiva asume en los más variados proyectos de rememoración. Resaltamos, desde nuestra comunidad interpretativa, la importancia de, como antropólogos / visuales, reconocer, impulsar y aliarnos a los proyectos émicos de duración de los trabajadores de las ciudades contemporáneas.

Palabras clave: antropología visual y de la imagen: etnografía de la duración; memoria colectiva; trabajo ferroviario. 
1. INTRODUÇÃO: MEMÓRIAS FERROVIÁRIAS A PARTIR DE UMA PERSPECTIVA ETNOGRÁFICA

O trabalho como valor ritmou os diferentes ciclos econômicos no Brasil. Dos tempos de colonização aos tempos modernos, foram inúmeros os movimentos imigratórios, compulsórios ou livres que efetivaram uma política de ocupação, exploração, expansão e, por fim, urbanização e industrialização. Entre tantos empreendimentos econômicos, as estradas de ferro amalgamavam todos os citados motes para o projeto de desenvolvimento e de construção do estado-nação que emergia no mundo Ocidental moderno. Dessa forma, ao adentrarmos o século XX no Brasil, a imagem que prevalece é a do trabalho desenvolvido em atividades estratégicas para a economia, como motor de desenvolvimento. $\mathrm{O}$ destaque para a atividade ferroviária sintetiza o símbolo de uma cultura de conquistas, seja nos moldes da República ainda oligárquica seja nos padrões da República mais urbana e industrializada.

A atenção com que a Antropologia brasileira se voltou para estes processos históricos, na medida de sua atuação acadêmica na segunda metade do século XX, cedo se consolidou nas linhas de pesquisa da Antropologia do Trabalho e da Antropologia Urbana. Estes campos de conhecimento também se mostraram como objetos de pesquisa de interesse do Programa de Pós-Graduação em Antropologia (PPGAS), inaugurado nos anos 1980 na Universidade Federal do Rio Grande do Sul (UFRGS). Uma tradição que se mantém ainda hoje, mesmo que se apresente de forma mais complexa e entrecruzada por novos desafios e campos de interpretação, como discussões sobre memória, gênero, família, envelhecimento, patrimônio, imagem, política, meio ambiente, entre outros conceitos.

Assim, não é nenhuma surpresa que tenhamos por objetivo, neste artigo, trazer o relato de investigações etnográficas centradas no tema do trabalho como valor, convergindo interesses de pesquisas e trajetórias de pesquisadores(as). Mais especificamente, abordamos o tema da memória coletiva de trabalhadores ferroviários no Rio Grande do Sul. Propomos um texto-diálogo que reverbere experiências presentes em produções desenvolvidas para conclusão de graduação e de mestrado, elaboradas entre interlocutores(as) vinculados(as) ao modo de vida ferroviário.

As pesquisas seguiram as trilhas das estradas de ferro e de algumas de suas principais estações: Porto Alegre, como capital do estado, importante centro articulador dos interesses econômicos e comerciais da região. Assim, na área metropolitana, a primeira ferrovia instalada no Rio Grande do Sul alcançava São Leopoldo, cidade caracterizada pelo histórico de receber a imigração alemã, conhecida pelo seu pioneirismo em manufaturas e empresas familiares; Pelotas, uma estação que ganhou importância não só como região economicamente relevante em tempos do domínio da produção pecuária, mas igualmente como território estratégico de segurança nacional, por sua proximidade com as fronteiras de países de conquista hispânica; nas proximidades de Pelotas, destacam-se outras estações, como Rio Grande, porto no extremo sul do estado, e Capão do Leão, também localizada nesta região sul; além destas, outras linhas férreas levam nossa pesquisa às regiões serranas de imigração italiana, como Caxias do Sul e Bento Gonçalves, centro econômico 
da produção de uvas e de vinho; contando, ainda, com Passo Fundo, para inserir uma cidade da região missioneira.

Tivemos como interesse compartilhado as imagens-memória das cidades, do trabalho, das transformações urbanas e das múltiplas formas de duração (o envelhecimento, as memórias, os "usos e desdobramentos" dos patrimônios culturais, as sociabilidades no presente e os projetos de futuro), aspectos que reverberam também a crise das ferrovias no Brasil. Hoje, estas estações são apenas rastros de um passado recente considerado promissor. Nestas cidades ainda residem os(as) trabalhadores(as) ferroviários(as) aposentados(as) e/ou seus familiares, em sua maioria pertencentes a uma faixa etária dos sessenta aos oitenta anos. São estes os principais interlocutores de nossas pesquisas, pessoas com quem convivemos intensamente, graças ao seu consentimento e mesmo às suas demandas por nossos estudos antropológicos.

Sob a luz desse percurso de pertencimentos, os objetivos deste artigo são: a) narrar o trajeto e as convergências de formação e de pesquisa, pertencimentos institucionais e teórico-metodológicos, visando refletir sobre a particularidade das "etnografias da duração" (Rocha \& Eckert 2013) no contexto de patrimonialização das urbes contemporâneas; b) refletir, a partir de nossas experiências entre comunidades de trabalho, sobre os plurais e complexos percursos das memórias do trabalho, da ruína ao patrimônio; c) situar os narradores e os interlocutores de pesquisa a partir de seus "desejos de memória" (Rapkiewicz 2018), indicando a necessidade de os(as) antropólogos(as) da memória estarem sensíveis aos projetos êmicos de duração, indicando de que maneira se pode participar desses projetos.

\section{UMA ANTROPOLOGIA COM IMAGENS EM CONTEXTOS URBANOS}

$\mathrm{O}$ ato de escrever coletivamente e a sua permanência no tempo enquanto atitude de pesquisa dizem respeito a um trajeto compartilhado. A primeira característica, que dá base para essa produção em conjunto, é a nossa inserção no Núcleo de Antropologia Visual (Navisual) do PPGAS da UFRGS. Esse núcleo, com tradição na formação de pesquisa na área da Antropologia Visual, tem a coordenação de Cornelia Eckert, também orientadora de nossas pesquisas. O Navisual atua em parceria com o Banco de Imagens e Efeitos Visuais (BIEV), um projeto de pesquisa de Cornelia Eckert e de Ana Luiza Carvalho da Rocha. Ambos têm como marca a atuação coletiva, que se efetiva nas produções de entrevistas, artigos, relatos de pesquisa, apresentações de trabalho, saídas de campo e "etnografias de rua" (Rocha \& Eckert 2013), reuniões semanais, seminários de leitura, a manutenção expositiva da galeria "Olho Nu", ensaios fotográficos, crônicas fílmicas, oficinas sobre narrativas e imagens, eventos, intercâmbios, exposições e curadorias ${ }^{2}$.

Enquanto o Navisual atua, de forma sistemática, na formação em Antropologia Visual, o Banco de Imagens e Efeitos Visuais atua na produção de

1 A Galeria "Olho Nu", vinculada ao Instituto de Filosofia e Ciências Humanas (IFCH) da UFRGS, é um espaço expositivo, gerenciado pelo Navisual que recebe propostas expográficas de cunho etnofotográfico.

2 Citamos como exemplo o mais recente projeto, intitulado "Cartas aos narradores urbanos" (Braz et al. 2018). 
"coleções etnográficas em formato multimídia e etnografias hipertextuais sobre o patrimônio etnológico do mundo urbano contemporâneo" (Rocha \& Eckert 2015a: 48), a partir das pesquisas desenvolvidas pelas coordenadoras, bem como por orientandos, bolsistas e voluntários. A produção do BIEV é divulgada na internet (https://www.ufrgs.br/ biev/ - BIEV UFRGS 2018), sendo acessível ao público.

Com a influência dessa formação, buscamos atuar de maneira colaborativa e compartilhada, ao nos relacionarmos com linhagens de conhecimento, com as parcerias intelectuais e com as plurais relações de interlocução. Nesse contexto, Guillermo Gómez, vindo de graduação cursada na Universidade Federal de Pelotas (UFPel), iniciou participação no Navisual em 2016, em razão de seu mestrado em Antropologia Social. Atua no núcleo desde então, agora como doutorando do PPGAS/ UFRGS. Yuri Rapkiewicz, por sua vez, foi bolsista de iniciação científica (IC) de ambos os núcleos a partir de 2010, vinculado ao projeto "Trabalho e cidade: antropologia da memória do trabalho na cidade moderno-contemporânea", seguindo como pesquisador colaborador do Navisual e do BIEV até 2018, ano em que concluiu o mestrado no PPGAS/UFRGS.

Estes núcleos de pesquisa foram nossos espaços de produção e de reflexão sobre "o estatuto da representação etnográfica no contexto da cultura visual no mundo contemporâneo" (Rocha \& Eckert 2015a: 12). Seguindo essa linhagem, nos filiamos à prática da etnografia da duração (Rocha \& Eckert 2013).

A pesquisa de Ana Luiza Carvalho da Rocha e Cornelia Eckert possui o objetivo de propor, como abordagem antropológica, a etnografia da duração, sob o prisma da metodologia da convergência:

O que o método de convergência
aponta, no caso da antropologia
interpretativista que adotamos nos
estudos da etnografia da duração, é
compreender e interpretar os jogos
da memória coletiva. Não significa
admirá-los com os olhos do artista
ou fotógrafo, ou cronista ou cineasta,
mas questionar o sentido desta obra na
convergência com outras, homólogas, a
partir da trama de ideias que compõem
o dinamismo criador que encerra
suas formas e/ou estruturas (Rocha
\& Eckert 2013:64).

Os "jogos da memória" e suas "tramas de ideias" são organizados pela conduta colecionista engajada do antropólogo com os desejos de memória dos grupos pesquisados. Assim, pensar a partir da etnografia da duração significa considerar o fenômeno da memória desde sua pluralidade de imagens. Acessamos, enquanto etnógrafos da duração, as formas narrativas pelas quais essas imagens assumem continuidade no tempo, isto é, pelos "esforços" (Bachelard 1988) com os quais habitantes das cidades agenciam os tempos vividos em uma composição narrativa ${ }^{3}$. O "grau de imersão

3 O conceito de duração aqui referido provém de uma interpretação advinda da filosofia de Gastón Bachelard, em especial de suas obras “A dialética da duração”, de 1936, e “A intuição do instante”, de 1932 (Bachelard 1988, 2010), e, posteriormente, de Gilbert Durand, com a obra "As estruturas antropológicas do imaginário”, de 1984 (Durand 2002). Tratar do tempo na sua rítmica afasta nossa perspectiva de outras apropriações conceituais da duração, tais como as de Henri Bergson. Para Bergson, a memória "é um ato de resistência da duração à matéria puramente espacial ou 
do antropólogo nos jogos da memória do outro" (Rocha \& Eckert 2013:54) está relacionado com sua compreensão das "identidades do si mesmo" (Ricoeur 1991), narradas pelos interlocutores. A identidade narrativa, enquanto gesto criador e modo de articular os tempos vividos, é um projeto de continuidade frente às descontinuidades e às rupturas temporais. Esse "desejo de transcender o tempo" (Rocha \& Eckert 2013:27) não diz respeito somente ao indivíduo, como ensina Maurice Halbwachs (2006), pois sua memória, apoiada e tramada às memórias de sua comunidade afetiva, faz vibrar as imagens-memórias do coletivo.

Se este fenômeno "raro" (Bachelard 1988) que é a memória está repleto e faz suscitar as mais variadas imagens, nossa aproximação das memórias e do imaginário dos habitantes das urbes contemporâneas demanda uma abordagem antropológica bastante específica:

Para investigar esse fenômeno da memória, portanto, não há outra forma senão aderir a essa dinâmica das imagens, mergulhar nas imagens em que o próprio narrador se deixa navegar, para encontrar as suas razões para durarem na paisagem do mundo contemporâneo (Devos 2005:17).

Imagens são, portanto, a maneira pela qual acessamos o mundo do outro e como "narramos" (Rocha \& Eckert 2005) essa relação de interlocução. Nesse sentido, cabe ressaltar duas questões importantes: 1) quando falamos em "imagem", estamos fazendo isso a partir da perspectiva durandiana do "imperialismo das imagens" (Rocha \& Eckert 2013:59), que significa reconhecer que elas podem ser sonoras, visuais, escritas, fílmicas etc.; 2) a compreensão dos regimes de imagens perpassa a produção, por parte dos(as) antropólogos(as), de outras imagens que - engendradas por categorias, princípios de sentido e núcleos semânticos em formas constelares - dão vazão à experiência etnográfica de interlocução, arranjando-as em formato imagético-narrativo.

\section{A DURAÇÃO DE UMA TRAJETÓRIA COLETIVA}

Há outra influência que inspira o pensar antropológico colaborativo defendido por nossas pesquisas: as próprias características do campo etnográfico investigado, isto é, do trabalho ferroviário. Esta atividade era organizada em rede, envolvendo desde o nome da principal empresa estatal que controlava a maior parte das linhas férreas no país - a Rede Ferroviária Federal Sociedade Anônima (RFFSA) -, passando pela estrutura de níveis e posições dispostas em organogramas, chegando até as microcooperações entre os diferentes setores nos processos de trabalho.

Ainda que o modelo de trabalho ferroviário buscasse aproximar as camadas trabalhadoras do espaço urbano controlado pela empresa, por meio das vilas operárias (Leite Lopes 1978), ou que produzisse um "encapsulamento das redes sociais" (Hannerz 2015), fazendo com que colegas de trabalho fossem também familiares e

intelectual" (apud Rocha \& Eckert 2013:28). Bachelard e Durand rejeitam as premissas bergsonianas, não reduzindo a memória a um fenômeno da consciência (cf. Rocha \& Eckert 2000), apostando na potência da imagem e do imaginário. A fenomenologia da imaginação, à qual a etnografia da duração mostra-se pertencente, apresenta uma contestação às antíteses bergsonianas, especialmente no que tange ao caráter secundário que seu pensamento atribui à imagem. 
vizinhos, o "enraizamento de uma comunidade de trabalho" (Eckert 2012) se dava de maneira particular. Os deslocamentos, característica dessa profissão, ressoam nas memórias que acessamos durante os itinerários de campo. Nossos universos de pesquisa ${ }^{4}$ acompanharam, assim, os fluxos e os deslocamentos na medida em que não obedecem a uma circunscrição geográfica específica, pelo contrário, nossas etnografias acessaram memórias plurais em movimento, em uma composição de camadas biográficas, culturais, societárias e de Estado. Nesse contexto, as imagens e as memórias do trabalho ferroviário sugeriram-nos tanto os encontros afetivos e etnográficos com os interlocutores ferroviários aposentados quanto com as organizações de convergências de narrativas imagéticas que abarcam diferentes territórios do Rio Grande do Sul.

Esse empreendimento de convergência entre nossas pesquisas, inspirado pelas diferentes razões que apresentamos até aqui, já tem, em si mesmo, uma duração no tempo. Além de termos como influências algumas das leituras clássicas da Antropologia Urbana brasileira (os narradores urbanos ${ }^{5}$, como Gilberto Velho, Ruben Oliven, Eunice Durham, Ruth Cardoso, Hélio Silva e Tereza Caldeira) e as referências da Antropologia do Trabalho (Leite Lopes 1978; Eckert 2012; Cioccari 2015), damos também destaque para interlocutores do nosso programa de pós-graduação. Um dos exemplos é Lucio Lord (2002), pioneiro em tomar a memória coletiva ferroviária em Porto Alegre como objeto de investigação etnográfica no âmbito do Navisual e do BIEV. O pesquisador centrou sua etnografia na vila ferroviária e no pátio de operações dos trens, ambos localizados no bairro Humaitá, em Porto Alegre. Outra leitura importante foi a da antropóloga Rojane Brum Nunes (2013), cuja pesquisa, realizada no município de Santa Maria (importante entroncamento ferroviário no Rio Grande do Sul), narra a apropriação da urbe pelos aposentados, em um revigorante estudo sobre processos de envelhecimento.

Assim, no que diz respeito à nossa primeira parceria, momento no qual nos propusemos a realizar exercícios de escrita e de bricolagem (Benjamin 1989), realizamos um ensaio fotográfico (Rapkiewicz \& Gómez 2016), mobilizando imagens colecionadas desde a graduação. As fotografias deste ensaio estão imersas nas narrativas das "sentinelas da memória” ferroviária no Rio Grande do Sul. Já no campo das publicações, o capítulo "Entre trilhos e temporalidades: o tempo do trabalho nas memórias dos ferroviários aposentados de Porto Alegre" (Rapkiewicz \& Eckert 2015) foi síntese do trabalho de conclusão de curso da graduação em Ciências Sociais de Yuri

4 Magnani $(2002,2012)$ chama atenção para que os antropólogos urbanos não caiam na “tentação da aldeia”, isto é, de estabelecer fronteiras bem definidas para um grupo social, dentro das quais poderia se apreender sua totalidade. Argumentamos que pesquisar sobre a fluidez das memórias e de seus jogos temporais e imagéticos, tecidos pelas narrativas dos interlocutores, é um ato de potência para transcender o tempo cronológico ou a delimitação geográfica das espacialidades.

5 A coleção intitulada "Narradores urbanos" é composta por vídeos-entrevista feitos com alguns dos principais antropólogos(as) urbanos(as) do Brasil. Foi organizada e distribuída pelo BIEV a partir de 2010 (BIEV UFRGS 2018). 
Rapkiewicz e integrou o livro "Etnografias do trabalho: narrativas do tempo"6.

Em nossas dissertações de mestrado (Gómez 2018a; Rapkiewicz 2018), evidenciamos com mais fôlego os argumentos apreendidos em cada experiência etnográfica. Gómez (2018a) seguiu as narrativas da crise ferroviária desde as condições de inserção profissional, passando pela manutenção de projetos de estabilidade e pela memória do trabalho e a interação mnêmica com documentos, instrumentos e veículos de trabalho e paisagens. Destacou a especificidade narrativa dos modos temporais e imagéticos de narrar o "fim" do trabalho, acompanhando, também sob a chave interpretativa do tempo e da imagem, os projetos de resiliência, crítica e indignação durante o envelhecimento e/ou aposentadoria.

Já Rapkiewicz (2018) ${ }^{7}$ apresentou narradores aposentados, colecionadores e militantes da memória ferroviária, agregando reflexões sobre o papel do antropólogo urbano e da restituição no âmbito de pesquisas relacionadas ao campo do patrimônio cultural. Neste estudo, os ferroviários narradores contam suas biografias de trabalho e de militância política pela memória social da ferrovia. Contextualmente, a etnografia acompanhou projetos de duração associados aos desejos de memória do grupo no Sul do Brasil, observando como os "etnocolecionadores" (Rapkiewicz 2018) são os guardiões protagonistas das histórias de trabalho que significam, no tempo presente, o patrimônio cultural ferroviário. Nesse entremeio, a pesquisa dialogou com a burocracia e os dispositivos de Estado que legitimam a continuidade formal deste recorte da memória industrial do país, abordando as políticas públicas de memória do Instituto Brasileiro de Museus (IBRAM) e do Instituto do Patrimônio Artístico Nacional (IPHAN), de forma aplicada ao cotidiano dos interlocutores da pesquisa.

Ao longo das investigações, compartilhamos os resultados parciais das pesquisas em alguns dos principais fóruns de discussão da Antropologia e das Ciências Sociais, como a Reunião Brasileira de Antropologia (RBA), a Reunião de Antropologia do Mercosul (RAM) e nos encontros da Associação Nacional de PósGraduação em Ciências Sociais (ANPOCS), nos quais buscamos dialogar por meio de campos temáticos como os estudos antropológicos do envelhecimento, da imagem, da memória, do patrimônio e do trabalho. Na $30^{\text {a }}$ RBA, o tema em foco consistiu no estudo de apelidos ferroviários, resultando posteriormente no

6 Este livro (Rocha \& Eckert 2015b) esteve vinculado ao projeto denominado "Trabalho e cidade: antropologia da memória do trabalho na cidade moderno-contemporânea”, com a participação de diferentes pesquisadores(as) do campo da Antropologia do Trabalho pertencentes ao Navisual e ao BIEV, como Ana Paula Marcante, Luisa Dantas, Rafael Lopo, Maria Cristina França, Fernanda Nummer, Olavo Ramalho, Marize Schons, Pedro Paulo Soares e Viviane Vedana.

7 Cabe registrar que a ferrovia abordada na dissertação de Rapkiewicz (2018) é um fragmento memorial afetivo e familiar, relacionado ao trabalho do avô paterno de Yuri, que havia servido no Batalhão Ferroviário, em Bento Gonçalves. A primeira entrevista desta etnografia foi realizada com Casemiro Rapkiewicz, o soldado 1.029, seu avô, que havia servido em 1950 na serra Gaúcha. Ele narrava, em 2010, ao lado do fogão a lenha, as suas histórias do quartel. Contava sobre a sua função de abrir picadas no mato e nivelar o terreno para instalação posterior dos trilhos, bem como sua rápida participação, já que foram apenas três meses de atividade, até ter sido definitivamente afastado do trabalho por um acidente. 
artigo de Magni \& Gómez $(2017)^{8}$. No $41^{\circ}$ Encontro da ANPOCS, debatemos como os rumores, enquanto uma peculiar forma narrativa, podem ser úteis para entender a crise ferroviária (Gómez \& Rapkiewicz 2017) e discutimos sobre coleções etnográficas e restituição no âmbito das pesquisas sobre a patrimonialização do complexo ferroviário e portuário de Porto Alegre (Rapkiewicz \& Abalos Junior 2017). Na XII RAM, aproximamos duas biografias de ferroviários aposentados, de Hélio Bueno (artífice da via permanente) e de Orlando Chagas (maquinista), para refletir sobre a complexidade do envelhecimento entre camadas trabalhadoras urbanas.

Nesse deslocamento, evidenciam-se diálogos com nossos coetâneos, como a coordenadora do projeto "Memorial da Estação Férrea de Pelotas” e orientadora de graduação de Guillermo Gómez, professora Claudia Turra Magni (Magni \& Gómez 2017), além da equipe interdisciplinar que acompanhou a pesquisa no ano de 2015 junto ao Laboratório de Ensino Pesquisa e Produção em Antropologia da Imagem e do Som (LEPPAIS/UFPel). Destacamse também parcerias construídas com a mestra em antropologia Andressa Pereira (Pereira 2017) e com a Rádio Comunitária de Pelotas (RadioCom), as quais possibilitaram, nas palavras do ferroviário Orlando Chagas, tornar "a cultura transmissível".

Yuri Rapkiewicz, como mediador cultural e estagiário do Museu do Trem de São Leopoldo entre os anos de 2012 e 2014, firmou parcerias com seus colegas da instituição de memória. Assim, produziu um artigo sobre a experiência crítica do programa de "Ação Educativa" do museu, dialogando sobre o cotidiano de trabalho e os projetos do Museu do Trem (Benvenuti et al. 2013). No âmbito dessa mesma experiência, integrou a equipe do projeto cultural "A tecnologia resgatando a memória ferroviária do Rio Grande do Sul”, realizado no biênio 2016/2017, no qual atuou com a pedagoga Lucélia Toldo de Souza e o historiador Ícaro Estivalet (Estivalet \& Rapkiewicz 2017). Ainda no âmbito dessas discussões sobre a memória ferroviária, localizamos a dissertação de mestrado em História de Cinara Isolde Koch Lewinski (2017), que também é colaboradora do Museu. Sua produção aborda o contexto histórico e social da implementação do centro de preservação da história ferroviária do Rio Grande do Sul (Museu do Trem de São Leopoldo).

\section{ETNOGRAFIAS DA DURAÇÃO FRENTE ÀS CRISES DA FERROVIA SUL-BRASILEIRA}

Antes de adentrarmos nas constelações imagéticas que escolhemos como fomentadoras do debate sobre patrimônio ferroviário e projetos de memória, retornamos aos fragmentos do contexto geopolítico local e global no qual as ferrovias brasileiras se inseriram ao longo do tempo. Afinal, a historiografia do tema (Flôres 2007; Harres 1996; Heinen 1981) teve destacada contribuição para a compreensão dos cenários nos quais se desenham esses projetos de duração, em consonância com a prática etnográfica de reminiscências da comunidade ferroviária. 
Falar sobre a "situação ferroviária contemporânea" é apresentar, reconhecer e valorizar as memórias de uma profissão que teve papel de destaque nos processos de urbanização e de industrialização do Brasil. O seu protagonismo, como "setor estratégico" das políticas de desenvolvimento econômico nacional (Simões 2004:29), foi diminuído ao longo das décadas, principalmente com os robustos investimentos no sistema rodoviário registrados a partir da década de 1950. Logo, identificamos a presença ferroviária no Rio Grande do Sul colocando em relevo os "jogos da memória", que trazem para a pauta essas continuidades, rupturas e transformações.

Em nível internacional, os primeiros trens surgiram na Inglaterra, com o advento da tecnologia da máquina a vapor. Eram visíveis os impactos da Revolução Industrial e do capitalismo financeiro como fatores determinantes para a proliferação de trens pelo mundo, consequentemente desencadeando o desenvolvimento industrial e a ascensão dos núcleos urbanos (cf. Hobsbawm 1977:72). No Sul do Brasil, a implementação das ferrovias serviu à necessidade de modernizar o transporte entre as zonas de produção agropecuária e as regiões portuárias, onde os produtos eram embarcados em navios para fins de abastecimento interno e exportação ultramarina. As linhas férreas também tiveram como importante papel o reconhecimento e a guarnição das fronteiras, ainda bastante conflitivas naquele contexto do final do século XIX.

O desenvolvimento da infraestrutura férrea foi possível por meio de vantagens econômicas e comerciais concedidas aos investidores estrangeiros por parte do governo imperial brasileiro, visando o custeio da construção e a manutenção das estradas de ferro. Durante as primeiras décadas (18701920), foram diversas as companhias estrangeiras que obtiveram o controle da malha ferroviária do estado, sendo a principal delas a Compagnie Auxiliaire de Chemins de Fer au Brésil, formada por capitais belgas, que, desde 1898, operavam no Rio Grande do Sul. Em 1905, a Compagnie adquiriu o privilégio de arrendar todos os ramais ferroviários rio-grandenses, unificando a malha ferroviária dessa região. Em 1920, com a criação da Viação Férrea do Rio Grande do Sul (VFRGS), o governo provincial encampou os caminhos de ferro do estado, quando, então, em 1957, a empresa pública estadual foi absorvida e federalizada, integrando o patrimônio da Rede Ferroviária Federal Sociedade Anônima (RFFSA), já no governo de Juscelino Kubitschek, que tinha a intenção de organizar um plano ferroviário nacional. A RFFSA foi "formada a partir da união de dezoito das vinte e duas ferrovias estatais então independentes" (Paradela 1998:54), mas a sua criação já era uma espécie de resposta ao cenário de precarização das ferrovias, porém "as subvenções foram incapazes de evitar a constante deterioração do setor, que continuou em queda na sua participação" (Silva Junior 2007:27).

Na década de 1990, a RFFSA entrou em fase de desestatização, signo bastante representativo do processo de declínio em que se encontrava esse modelo de transporte no Brasil'. Mais recentemente, um conglomerado privado norteamericano começou a administrar as estradas de ferro do Rio Grande do Sul e de outras regiões

9 Sobre a privatização da RFFSA, ver Amorelli (2003), Nunes (2016) e Paradela (1998). 
brasileiras a partir de 1997, quando adquiriu este direito por meio de concessão, firmada no primeiro mandato do presidente Fernando Henrique Cardoso. O evento de desestatização das ferrovias, enquanto marco temporal da extinção da RFFSA, é lembrado pelos aposentados com tristeza e indignação, denominando-o de "fim da ferrovia". Esse fim tem "plurais expressões e formas narrativas" e, inclusive, imagéticas particulares (cf. Gómez 2018b).

Em contraponto à situação atual de terceirização e de precarização das condições de trabalho, os narradores ferroviários vivenciaram um período em que a prestação de serviços e as relações hierárquicas eram geridas por um "gigante burocrático”, com quase 160 mil funcionários em seu auge (Rapkiewicz \& Eckert 2015; Amorelli 2003). Ainda hoje, a comunidade ferroviária faz referência à RFFSA mediante o uso de metáforas como "família" e "mãe carinhosa" - ou, no caso de sua ausência, se colocam como "órfãos" ou "viúvos" da empresa. Além desses termos associados a um glossário paternalista, é corrente a menção a ela apenas pelo termo "Rede".

A "Rede" era portadora de uma estrutura assistencialista, ofertando moradia, escola, assistência familiar, lazer, serviço de saúde, previdência social e planos de carreira. Esse modelo institucional, baseado nas políticas de longa permanência, típicas de um modelo de capitalismo social (Sennett 2015), fazia com que ingressar na profissão ferroviária fosse um projeto de vida almejado. O principal motivo que incentivava a entrada na profissão era a "conquista da estabilidade" (Gómez 2018a), princípio de distinção entre as camadas trabalhadoras urbanas. Claro que esses atrativos também configuravam as exigências da "disciplina empresarial" (Palermo 2012), isto é, moldavam os trabalhadores em um regime de controle, necessário para a reprodução do capital ${ }^{10}$. Em entrevista a Guillermo Gómez, um empregado da Rumo Logística declarou:

E a gente tem hoje um coordenador. Exemplo: lá em Rio Grande, hoje, são dois coordenadores. Para ti só ter só uma noção, no tempo da rede ferroviária, todo mundo era engenheiro. Tinha uns oitocentos engenheiros, era engenheiro da via permanente, era engenheiro da estação, era engenheiro de maquinista... Todo mundo era engenheiro! Inclusive os caras tinham mania de ser chamado de doutor, nunca tiveram doutorado nenhum, mas Deus me livre se não chamasse o cara de doutor fulano de tal. Hoje a gente tem dois coordenadores, $\mathrm{e}$ só! Rio Grande ali, na época, ali ficavam os engenheiros tudo, se a gente fosse contar, tinha uns 50, ali, mais ou menos. Hoje são dois coordenadores. Dois coordenadores a gente faz tudo, muito mais do que antes,

10 Nesse sentido, a empresa burocratizou sua estrutura, num modelo que perpassava toda vida social dos trabalhadores, disciplinando-os (cf. Lord 2002:55): “[...] burocratizar e hierarquizar em seu corpo administrativo, as organizações operariadas, a empresa fez obrigatória a inscrição e pagamento de taxas por parte dos operários a essas organizações. Dentro desse novo sistema entram organizações como a Sociedade Beneficente, criada para substituir a Liga Operária formada pelos operários, e a Associação Protetora, também originalmente formada pelos operários. Ainda fez parte do sistema de dominação paternalista, a construção de casas operárias pela empresa. [...]”. Em última instância, a moradia operária seria a forma mais direta de controle da empresa sobre a família operária, conforme mostra Leite Lopes (1978). 
com dois caras. Para ti ver a mudança. (Ubirajara, 62 anos, comunicação pessoal, 12 set. 2017).

Mais recentemente, a empresa norte-americana responsável pelas linhas férreas tem operado com terceirização das funções de trabalho, pulverizando as vinculações institucionais mais diretas e reduzindo o quadro profissional de especialidades para execução de processos cotidianos de trabalho. Um bom exemplo nesse aspecto é o dos maquinistas e dos auxiliares que viajavam juntos e tinham responsabilidades complementares até a década de 1990. Após a exclusão da categoria dos auxiliares, as tarefas de duas pessoas foram assumidas unicamente por um trabalhador. O agente de estação aposentado Ricardo Reischak conta que:

[...] foi no Plano de Cargos e Carreiras (PCC) revisado da RFFSA em 1990. $\mathrm{Na}$ oportunidade, os auxiliares de agente de estação passaram todos para agentes especiais de estação, assim como os artífices mecânicos, metalúrgicos, eletricistas e afins, que foram classificados como artífices de manutenção. Algumas funções foram extintas, como operador de telex, camareiro e etc. (Ricardo Reischak, 55 anos, comunicação pessoal, set. 2016).

As equipes de artífices da via permanente também foram reduzidas numericamente e suas famílias deixaram de habitar as casas das vilas ferroviárias. Havia aposentadorias, mas não eram feitas novas contratações e, assim, a ausência de trabalhadores, de ferramentas, de equipamentos e de maquinários foi se manifestando de forma lenta. Aos poucos, os próprios ferroviários podiam perceber que este "esvaziamento" da RFFSA anunciava o pior. Não poderiam imaginar que, após o sucateamento, viria a extinção da empresa. O que era apenas rumor tornou-se um fato irreversível. O maquinista, que já viajava sozinho por trechos precários de ferrovia nos quais arrastava a composição de locomotivas e vagões a baixas velocidades durante os últimos anos da "Rede", passou da condição de "trabalhador só" para desempregado. Assim, o processo de sucateamento da malha ferroviária ("ou projeto", como nos colocam alguns interlocutores) é narrado com pesar pelos trabalhadores. O abandono de construções da antiga empresa estatal, por exemplo, é um aspecto destacado no discurso de indignação de muitos ferroviários aposentados: "esta situação não é justa com os tantos anos de trabalho que desempenhamos como ferroviários" (Hélio Bueno da Silveira, 77 anos, comunicação pessoal, out. 2010).

É nesse contexto de crise (Eckert 2012) conceito de que fazemos uso para referenciar a ruptura dramática com os tempos ritmados pelo trabalho - que se politiza a necessidade de uma investigação sobre as memórias ferroviárias. Mas não devemos nos enganar, temos consciência de que não podemos nos colocar enquanto "antropólogos frente ao dilúvio” (Marcus 2016) ${ }^{11}$, recuperando uma tradição clássica da Antropologia de preservar culturas em face de desaparição. Estamos sensíveis às transformações da história e da economia política, como as narram os interlocutores, sem essencializar ou idealizar o passado ou, de outro

11 George Marcus (2016) direciona sua crítica para modos etnográficos de lidar com a mudança histórica, chamados por ele de "modo de resgate" e de "modo redentor" (Marcus 2016:237). No primeiro, os "sinais de mudança são 
lado, condenar, de maneira quase sadista (cf. Ortner 2016), o tempo presente, de contexto neoliberal.

Advogamos a favor da manutenção e do reconhecimento dos "desejos de memória” (Rapkiewicz 2018) da comunidade ferroviária em suas mais diversas expressões. Ao indicarmos essa dimensão política e cotidiana da memória, queremos enfatizar inúmeras atividades resilientes dos(as) sujeitos(as) para fazer suas biografias e sua comunidade de pertença durarem no tempo. Se, como nos ensina o mestre da memória coletiva, "esquecer um período da vida é perder o contato com os que então nos rodeavam" (Halbwachs 2006:37), interpretamos as identidades narradas dos ferroviários(as) enquanto esforços coletivos e "teimosos" (Certeau 1994), que integram uma duração "ordinária" e que insistem em se insubordinar perante as descontinuidades.

Enquanto antropólogos, ao longo dos anos de pesquisa, fomos percebendo que os interlocutores nos transformavam em "aliados" dessa politização da memória. Faziam com que nossa atuação, seja em projetos acadêmicos seja nos poderes públicos, funcionasse como eixo propulsor da memória coletiva da ferrovia no sul do Brasil.

\section{CONSTELAÇÕES DE IMAGENS}

A Antropologia Visual teve e tem um papel preponderante na parceria engajada dos projetos de duração. A antropóloga Ana Lucia Ferraz cuja tese de doutoramento resultou do estudo realizado entre grupos de trabalhadores na região metropolitana de São Paulo (Ferraz 2009a) enfatiza, com influência de Jean Rouch, que a
Antropologia Visual permite "a participação do grupo estudado na produção das representações etnográficas" (Ferraz 2009b:83). No contexto de produção compartilhada de vídeo etnográfico em etnografias do/no mundo do trabalho, a autora destaca que "falar para a câmera trazia a possibilidade de emergência de discursos silenciados em outros espaços, como a assembleia, ou em reuniões formais" (Ferraz 2009b:88).

Nesse mesmo sentido, as exposições e os ensaios fotográficos, as atividades em museus e escolas, as projeções de vídeos-documentários e a circulação de museu de rua que fizemos colocaram a imagem como central nos projetos de duração da memória coletiva do trabalho ferroviário. Nossa tarefa foi, em um primeiro momento, reconhecer quais eram os projetos êmicos de continuidade da memória, entender e interpretar, ao modo antropológico, suas "teias de significados" (Geertz 2014) para, em segundo plano, durante o aprofundamento das relações em campo, conseguir efetivamente se inserir nas redes de memória e transformar o imperativo de duração da memória ferroviária em um trajeto antropológico compartilhado.

Nossas narrativas imagéticas passaram a contar com a vibração dos acervos pessoais, públicos e privados, com os prints de indignações manifestadas na internet, com as narrativas cotidianas presentes nos bairros de moradia, registrados em nossas fotografias e em nossos diários de campo. Logo, a memória ferroviária efervesce em múltiplas imagens e arranjos temporais, tomando forma nas coleções

evidentes, mas o etnógrafo é capaz de resgatar um estado cultural à beira da transformação” (Marcus 2016:237). No segundo, "o etnógrafo demonstra a sobrevivência de sistemas particulares e autênticos, apesar das inegáveis mudanças" (Marcus 2016:237). 
etnográficas de nossas pesquisas. Nossas constelações de imagens, apresentadas neste artigo, se entrelaçam às ressonâncias dos projetos "Memorial da Estação Férrea de Pelotas", "Centro Cultural Grêmio Esportivo Ferrinho" e "A tecnologia resgatando a memória ferroviária do Rio Grande do Sul”.

Destacamos esse contexto de alianças nos projetos de duração e de afirmada militância compartilhada na manutenção da memória ferroviária, justamente em face da crise das ferrovias brasileiras, mas, especialmente, da precarização do "público" enquanto conceito e setor de empregos, da redução de iniciativas nos setores da cultura e da educação e, mais atualmente, de enxugamento do Estado. Dessa forma, a experiência de gerações de famílias, avós, pais e netos que ingressavam na profissão da vida sobre os trilhos, ressoa agora na forma de memórias narradas e patrimônios preservados ou ameaçados. No caso de nosso universo de pesquisa, a categoria profissional que possui um histórico de greves e de militância sindical e política em prol dos trabalhadores atua tanto em adesão como em resistência frente às diversas políticas de governo disponíveis, embora mantenha um ativismo contínuo e duradouro em relação à fiscalização das condições materiais e subjetivas dos patrimônios ferroviários ${ }^{12}$.

Advogamos a favor do comprometimento antropológico com investigações em torno da memória, ancorados nos pressupostos de compreensão dos regimes êmicos de tempo e de valorização do repertório de imagens das culturas locais e periféricas. A abordagem da etnografia da duração, afinal, está preocupada com os processos de patrimonialização nas cidades contemporâneas, em suas diversas escalas e particularidades.
Mas, afinal, como optamos por materializar esse esforço nesse texto, escrito a seis mãos? Como não poderia deixar de ser, organizamos narrativas imagéticas, convergindo imagens suscitadas pelas experiências de trabalho de campo entre comunidades ferroviárias no Rio Grande do Sul. Não buscamos, com essas duas constelações, abranger a pluralidade de discussões abordadas até aqui, mas deixamos que as imagens e suas convergências levem a outras possíveis.

Cabe dizer que a constelação é, para nós, conceito teórico e expográfico. Não é possível pensarmos uma imagem isolada da outra, e assim procedemos nas diferentes instâncias em que as imagens de pesquisa vibraram. Nas exposições coletivas do Navisual ou em sua metodologia aplicada a cada contexto etnográfico, imagens sempre se dispuseram juntas, aproximaram-se, formaram narrativas. Portanto, é por meio das convergências que dispomos e apresentamos as imagens neste artigo.

Selecionamos dois conjuntos de imagens, cada qual com seus "núcleos semânticos organizadores de sentido nessas constelações" (Rocha \& Eckert 2013:57). Ambos estão vinculados às categorias centrais de "crise" e "duração", subscritas ao "tempo" enquanto categoria predominante. Entendemos crise como a ruptura de uma rítmica temporal e duração como o esforço manifesto por sua continuidade. Destas categorias, na primeira constelação, desdobram-se as categorias de "ruína" e de "patrimônio", nas quais oscilam a "degradação" e a "recuperação", a "cidade" e o "trabalho". Na segunda constelação, a transformação da crise em duração se dá pelos atos de politização da memória, pelo "envelhecimento resiliente", pelas vibrações da memória do trabalho em diferentes suportes, aspectos que, em suma, efetivam "projetos de duração".

12 Sobre o tema da adesão ou da resistência frente às políticas culturais de patrimônio, ver Lima Filho (2015). 


\section{ESTAÇÕES FERROVIÁRIAS: DAS RUÍNAS DO TRABALHO AOS PATRIMÔNIOS DAS CIDADES}
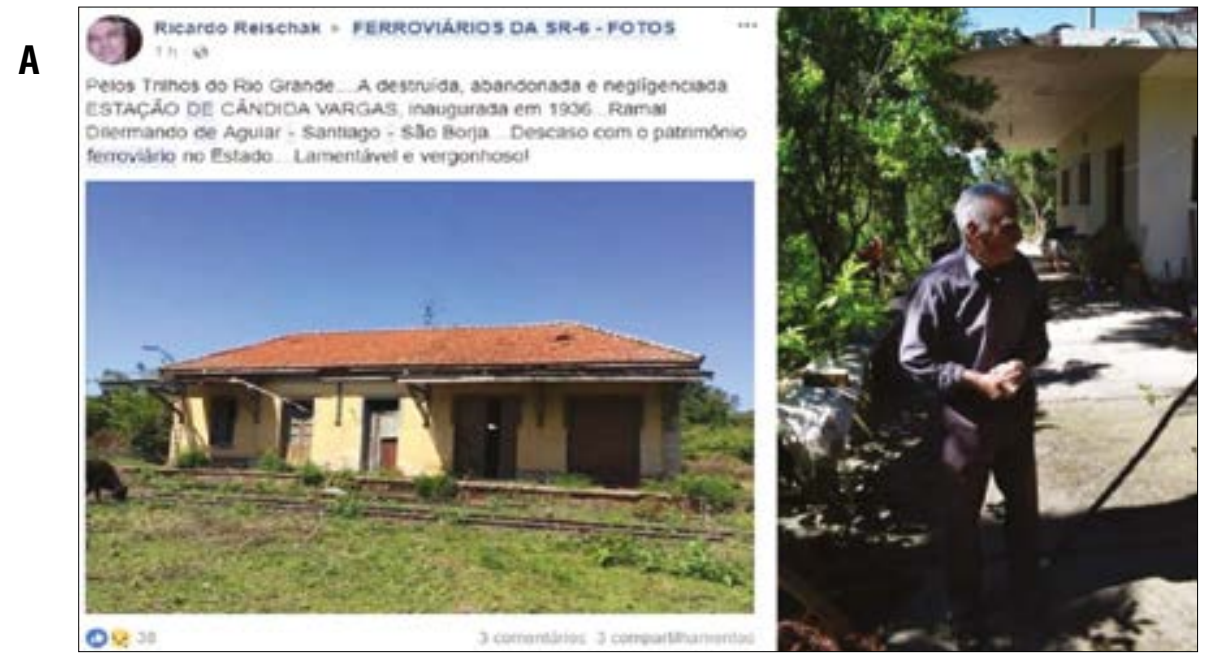

B

Figura 1 - A) Imagem retirada do Facebook; B) fotografia de Yuri Rapkiewicz (2017).

A

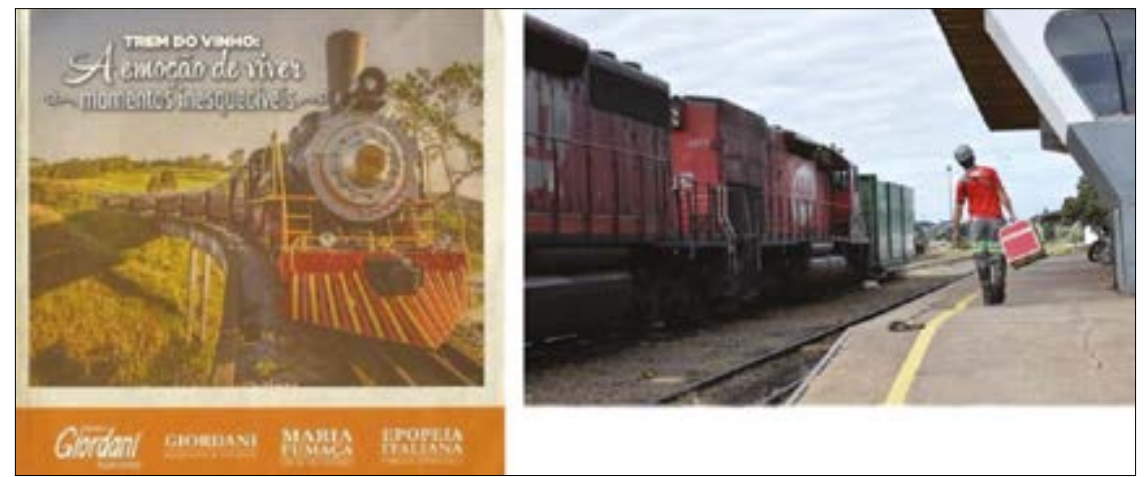

B

Figura 2 - A) Folder turístico; B) fotografia de Guillermo Gómez (maio de 2017).

A

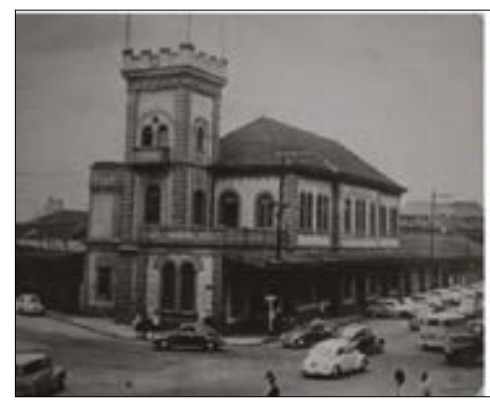

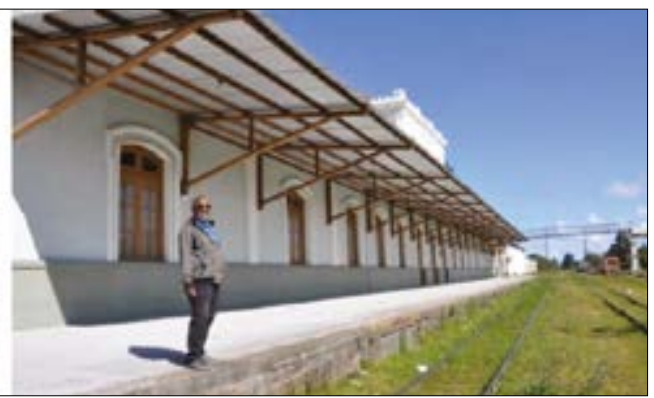

B

Figura 3 - A) Imagem de acervo do Museu do Trem; B) fotografia de Guillermo Gómez (setembro de 2016).

Nessa constelação, acompanhamos o paradoxal década de 1990, apenas deu fim a um longo e agonizante cenário contemporâneo das ferrovias no Brasil. A processo de abandono, que durou décadas. Como o extinção da RedeFerroviáriaFederal (RFFSA), no final da trabalho ferroviário é caracterizado pela dispersão da 
mão de obra por longas extensões do território, também dispersos estão seus patrimônios, sejam eles materiais ou imateriais. Após a dissolução da empresa, os terrenos e as habitações operárias ficaram em situação inconclusa juridicamente. Já as estações, clássico símbolo do ocidente, tiveram os mais variados destinos, que vão desde a patrimonialização até o completo abandono.

A Figura 1A é uma fotografia publicada pelo ferroviário Ricardo Reischak no grupo "Ferroviários da SR-6 - FOTOS", do Facebook. Esta "imagemdenúncia" ressalta o abandono da estação ferroviária Cândida Vargas, localizada no ramal desativado do trecho Dillermando Aguiar - Santiago - São Borja, na região central do Rio Grande do Sul.

O espaço virtual do grupo do Facebook ora mencionado é ocupado por trabalhadores, como os funcionários aposentados da RFFSA, parentes de ferroviários epesquisadores. Mais do que um repositório de imagens, é um lugar de sociabilidades, reencontros e desabafos entre os ex-colegas de ferrovia. Acompanhar as atualizações da plataforma online no que concerne à postagem de fotografias e aos comentários, bem como a "compartilhamentos e curtidas", evidencia os protagonismos, os conflitos e a diversidade de sujeitos imersos nessa temática, com diferentes posicionalidades e interesses. Segundo Gómez (2018a:186):

Estas ações nas redes sociais, enquanto manutenções da memória coletiva, contam com algumas características peculiares das informações que circulam na internet. A primeira delas é a efemeridade do registro, os dadosnãoestãoalipara seremacervadospara as futuras gerações. Mas é por meio de outra característica dasinformações compartilhadas emuma rede como o Facebookque se produz uma relaçãoímpar coma memória coletiva: a constante renovação e a periodicidade diária.
Esteusoêmico dasimagens permite que todos os dias se esteja relembrando, discutindo, denunciado assuntos relacionados à ferrovia. Uma rítmica singular da manifestação da duração deste grupo geracional, profissional e afetivo.

As estações desativadas, parte da imagética da crise ferroviária, também servem de moradia para famílias de ferroviários aposentados, fenômeno recorrente no Rio Grande do Sul. A Estação São Valentim (Figura 1B), pertencente ao Ramal do Vinho, na serra Gaúcha, por exemplo, é habitada por um casal de ferroviários: Inês Augusta Justina da Silva, 82 anos, e seu o marido, Garibaldino Alves da Silva, 81 anos. O aposentado narrou ter ingressado no Batalhão Ferroviário aos 19 anos. Durante a trajetória de trabalho, foi transferido para Lages, no estado de Santa Catarina, por curto período, retornando para o Rio Grande do Sul. Sobre a ocupação da Estação, relatou que ela estava desativada desde a década de 1970, e que ganhou o direito à moradia e às chaves do imóvel "da mão do Sargento Inácio". A casa poderia seguir sob a posse do aposentado, como reconhecimento pelos anos de profissão. Segundo o relato do casal, nunca foram importunados por residirem no "seu imóvel".

Apesar da crise, as estações ainda são espaços de trabalho, como vivenciamos em Passo Fundo (Figura 2B), recebidos por trabalhadores locais terceirizados. Porém, é claro que a "profissão ferroviária", tal como é desempenhada hoje, distancia-se muito das práticas rememoradas pelos aposentados. Foi o que narrou Ubirajara, trabalhador na cidade de Rio Grande, um dos poucos que atuaram na Rede Ferroviária e foram recontratados pelas concessionárias privadas:

Ubirajara: [...] a função mudou completamente. O Rubem, aquele que tu acompanhou ali, era da época que a 
gente trabalhava na estação, tudo passava por nós, os trens, documentação. Hoje, para ti ter uma ideia, o maquinista está escalado para um trem, digamos às 17 horas. Ele vai lá, entra na máquina, o trem tá pronto, tem um teclado que ele põe no colo ali, se comunica diretamente com Curitiba, ele licencia o trem dele, o cara diz ó tu tá autorizado a avançar até Pelotas e vai cruzar em tal lugar com outro trem. Guillermo: não se comunica mais com as outras estações?

Ubirajara: Nada, não existem mais as estações (Ubirajara, 62 anos, comunicação pessoal, 12 set. 2017, grifo nosso).

Em Pelotas, o ferroviário aposentado Orlando Chagas (Figura 3B), que vive "à beira dos trilhos", convive com a estação recuperada pela secretaria de cultura e pelo IPHAN, e conhece as promessas do poder público quanto ao estabelecimento de um memorial ferroviário. É o que conta ele, em fala proferida em um programa da Rádio Comunitária dePelotas (RadioCom), organizado em parceria com as redes de pesquisa:

Hojeagentejá ganhou váriosaliados. Agente játinhamuitaspessoas. Agenteganhou oseu Paulo e a RadioCom. Estamos empenhados em organizar o museu ferroviário. E onde a gente gostaria defazer omuseu ferroviário?É naferrovia, na estação. Temaquelememorial vivo, o nosso patrimônio, que é a estação, foi restaurado, e hoje funciona lá o Cerest e o Procon e nada, nada de ferroviário. Eu, que convivo ali diariamente, porque eu sou delegado sindical, representante aqui de Pelotas, eo sindicatoéaoladoda estação.Hoje, que que acontece, a gente tá convocando os ferroviários que todos que tiverem histórias, licenças, algo de ferroviários, que venham até nós, vai servir para nós começar a fazer nosso memorial. (Orlando Chagas, 61 anos, comunicação social, 27 jan. 2018).
A memória, reivindicada pelos ferroviários como patrimônio, também ganha matizes de "espetacularização emercantilização" em contextos turísticos. No Rio Grande do Sul, a cidade de Bento Gonçalves é o exemplo mais marcante (Figura 2A) . Lá, as imagens da ferrovia são transformadas em anúncios da experiência da "viagem do trem do vinho como um momento inesquecível". A estação ferroviária de Bento Gonçalves é atualmente gerenciada pela empresa Giordani Turismo, que administra o passeio no trem turístico Maria Fumaça. A viagem sobre os trilhos tem duração de $1 \mathrm{~h} 30 \mathrm{~min}$, percorrendo o vale dos Vinhedos (cidades de Bento Gonçalves, Garibaldi e Carlos Barbosa). A viagem, em clima de festa, é regada a vinho, espumante, canções italianas e danças regionais, encenadas por atores caracterizados. A passagem da locomotiva a vapor e o som do apito tornam-se o clímax do percurso. Na beira dos trilhos, a interação fugaz com os moradores ocorre por meio de acenos, palmas e gritos. Enquanto isso, no interior dos carros de passageiros, ocorre a incessante comercialização de quitutes, bebidas e souvenirs.

A imagem de acervo do Museu do Trem (Figura 3A) retrata a maior estação ferroviária de Porto Alegre, a Estação Castelinho, em um período de efervescência do sistema ferroviário no Rio Grande do Sul (década de 1940). Demolida na década de 1960, a construção deu lugar à avenida Castelo Branco, via de grande circulação da cidade, durante as transformações da infraestrutura urbana, que privilegiavam o setor rodoviário em detrimento das estradas de ferro. A presença de uma fotografia de acervo nesta constelação também abarca um horizonte comum das imagens por nós colecionadas, afinal, ao longo de nossas pesquisas, encontramos imagens de acervo em diferentes contextos: em coleções particulares ou museológicas, em álbuns de família e na internet. 


\section{PROJETOS DE DURAÇÃO E OS DESEJOS DE MEMÓRIA}
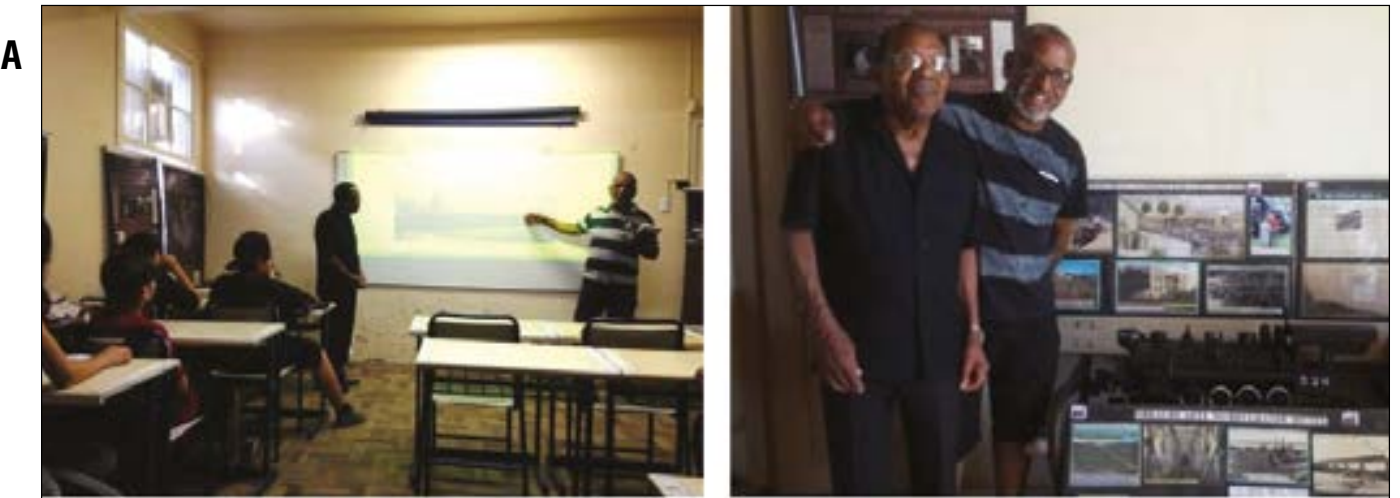

C

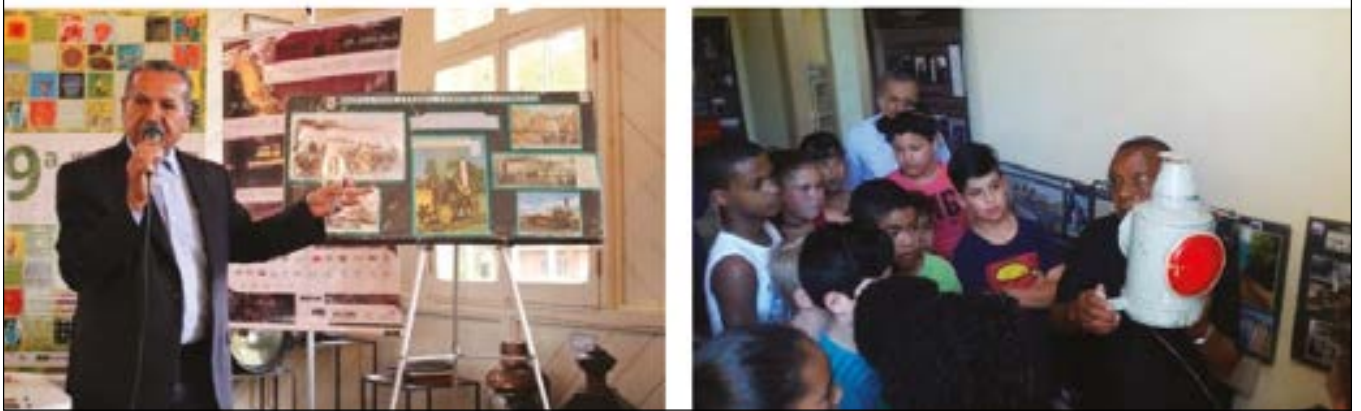

Figura 4 - Fotografias de Yuri Rapkiewicz (2011) e Guillermo Gómez (2018).

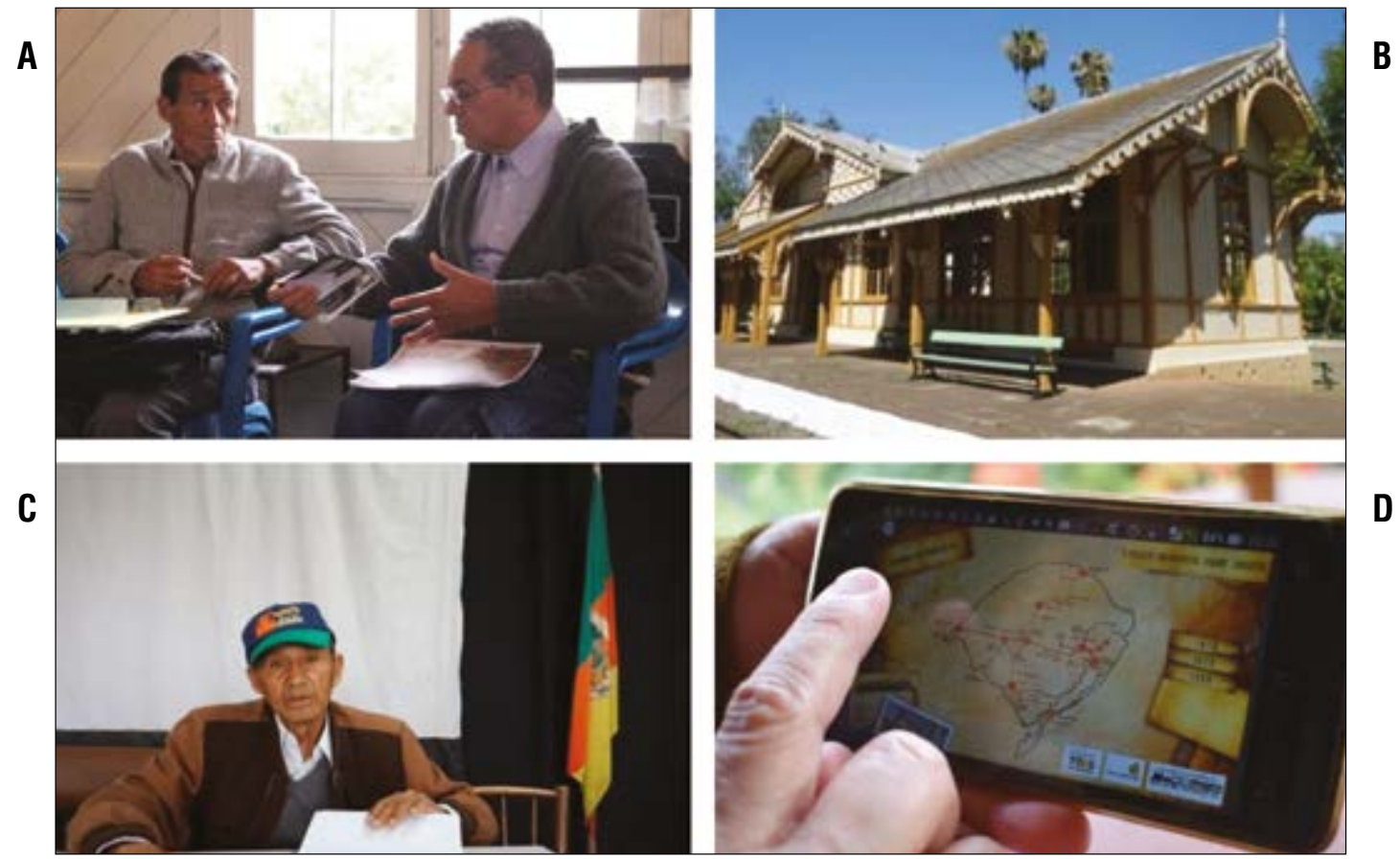

Figura 5 - Fotografias de Yuri Rapkiewicz (2011-2018) e acervo do Museu do Trem (2010). 
Nesta constelação, abordamos a complexidade dos jogos de memória, nos quais os velhos narradores agenciam politicamente suas imagens, fazendo vibrar as temporalidades do trabalho ferroviário. Como já afirmamos anteriormente, os projetos êmicos de continuidade, em suas variadas expressões, são importantes para nós. Também se faz fundamental a potencialização destes projetos, por meio da constituição de alianças que têm como contribuição engajada o próprio conhecimento antropológico. Destacamos o processo compartilhado no qual a memória do trabalho passa da reminiscência para a ação. Esses movimentos realizados pelos sujeitos de pesquisa nos colocam desafios, enquanto etnógrafos, de acompanhar outros contextos e situações. A etnografia passou a se situar nos museus, nas falas públicas, nas salas de aula, nos eventos acadêmicos, nas defesas de dissertação e na internet. Esses "outros espaços", ocupados pela comunidade ferroviária em seus projetos de duração, fizeram a memória do trabalho se transformar e se adaptar criativamente aos diferentes contextos.

Paulo Nilton de Carvalho (Figuras 4C e 5A) é conhecido entre os ferroviários por ser um protagonista na militância cotidiana pela memória coletiva. Desde que se aposentou, organizou uma exposição itinerante de painéis com suas próprias fotografias tiradas durante o período de trabalho ${ }^{13}$.

Boa noite, meu nome é Paulo Carvalho, estou com 81 anos. Em primeiro lugar agradecendo esta honra aqui, para mim, que tenho origem toda ferroviária, quando me convidam para fazer parte de uma programação, me emociona muito, apesar da idade. Até porque, esses dias - eu tenho uma exposição ferroviária - um repórter perguntava por que que eu tinha essa paixão pela ferrovia. Tem uma origem até na minha fabricação, quando meus pais me fabricaram dentro de um trem. Eles viajaram num trem quando casaram e esse trem ficou retido em Cruz Alta e dali a nove meses eu nasci. Esse é o sangue do ferroviário que eu levo e depois, várias outras coisas, mas é uma alegria grande estar aqui na presença de vocês (Paulo Carvalho, 81 anos, em participação no programa "Memória Ferroviária", veiculado na Rádio Comunitária de Pelotas em janeiro de 2018).

A exposição itinerante de Paulo já percorreu os municípios de Porto Alegre, São Leopoldo, Santa Maria, Rio Grande, Pelotas, Capão do Leão, Restinga Seca, Canela, entre outros. Os painéis são constantemente aperfeiçoados (em conteúdo e forma) pelo ferroviário, idealizador e curador. Sua circulação por diferentes municípios do estado faz vibrar e circular a memória do trabalho como parte fundamental da constituição desse "personagem" e da maneira pela qual ele se apresenta, fazendo, ainda, durar a biografia de sua comunidade afetiva.

Em Pelotas, os ferroviários aposentados Orlando Chagas (Figura 4A) e Rubem Medeiros (Figura 4D), são engajados com as repercussões

13 Paulo tem livro publicado com suas memórias, de autoria do historiador Humberto Calloni (2010) 
do Memorial da Estação Férrea ${ }^{14}$ e apresentam um verdadeiro conceito de memorial adaptado às práticas do dia a dia. Além da itinerância dos banners e do vídeo etnográfico (Figura 4B), organizamos, em 2017 e 2018, um conjunto de atividades que envolveram entrevistas na mídia local, programas de rádio e os encontros de gerações (Figuras 4A e 4D), com o apoio do Colégio Francisco Simões, da Casa de Cultura do Capão do Leão e da Escola Barão do Arroio Grande. Nestes encontros, os octogenários Paulo Carvalho e Rubem, junto com o delegado sindical Orlando Chagas, guiaram as crianças por uma exposição compartilhada (que contou com uma combinação dos acervos de pesquisa com os objetos pessoais do acervo de Paulo), na qual os instrumentos de trabalho, como lanternas e quepes, locomotivas em miniatura, somados à profusão de imagens dos painéis, fizeram com que o conhecimento do trabalho ferroviário e a memória cotidiana do ofício se tornassem um saber a ser transmitido. No colégio Simões, as imagens dos acervos pessoais dos ferroviários Orlando e Rubem, projetadas no Power Point, transformaram as memórias em conteúdo das aulas de geografia e de história. Após as intervenções, os ferroviários mostraram-se surpresos com a atenção que os alunos de $5^{\circ}$ ao $8^{\circ}$ ano dispenderam para suas falas. O embaraço inicial de falar perante o público logo esvaneceu e se apropriaram dos espaços com maestria. Seguem militando a favor da criação de um memorial no prédio recuperado da Estação Férrea de Pelotas e, enquanto isso, agregam ao repertório da duração atividades, habilidades e parcerias múltiplas.

No munícipio de São Leopoldo, a memória ferroviária recebe um tratamento institucional. Lá se encontra o edifício da primeira estação ferroviária do estado (1874), que hoje abriga o Centro de Preservação da História da Ferrovia no Rio Grande do Sul (CPHFRGS). O Museu do Trem (Figura 5B), como é comumente conhecido, é uma instituição municipal estabelecida em 1976. Atualmente, é catalisador de iniciativas em que os ferroviários aposentados são valorizados perante o público das escolas da região, com contínua visita de estudantes dos ensinos fundamental e médio. O Programa de Ação Educativa, criado em 2009 pelo Museu, abrangia visitas mediadas, o "cine-vagão", exposições permanentes e temporárias e oficinas de educação patrimonial e conservação de metais. O Museu do Trem também é receptor e multiplicador de projetos de políticas públicas patrimoniais, entre elas a Semana Nacional dos Museus. Essa temporada cultural ocorre anualmente no mês de maio e é organizada pelo Instituto Brasileiro de Museus (IBRAM). Assim, a equipe do Museu do Trem organiza um calendário de intervenções culturais, ligadas à temática proposta pelo IBRAM.

A agenda da Semana de Museus de 2012 incluiu as Rodas de Memórias temáticas, que foram oportunidades nas quais os ferroviários

14 Memorial da Estação Férrea de Pelotas é um museu de rua, itinerante, inaugurado em 2015, cujas últimas exposições, até a data desse escrito, foram em dezembro de 2018. 
aposentados compartilharam suas biografias de trabalho. Os ferroviários-colecionadores Hélio e Paulo (Figura 5A) integraram a programação do evento. As Rodas de Memória proporcionaram a interação entre ferroviários aposentados e jovens estudantes. Ao descreverem suas vivências, encontravam espectadores adolescentes atentos e curiosos, que ouviam os testemunhos de trabalho. As histórias de vida partilhadas no interior de um museu entre antigos colegas de trabalho e o público inscreviam o cenário onde se sobrepunham tempos distintos.

Durante a Semana de Museus, Hélio Bueno da Silveira (Figura 5C), militante da memória férrea e trabalhador aposentado da RFFSA, destaca que trabalhou "por trinta e dois anos, cinco meses e doze dias" na empresa estatal. Ele é morador da vila ferroviária de Porto Alegre e guardião do Grêmio Esportivo Ferrinho. O aposentado simboliza o Ferrinho como um espaço afetivo, parte importante de sua vida. Há muito tempo luta para transformar o local em um centro cultural de reconhecimento na cidade. O prédio, situado em área operacional da Rumo Logística, tem um nível de conservação precário, com pintura desbotada, infiltrações e rachaduras nas paredes. Hélio sempre esteve engajado na preservação do edifício, inclusive, em certo momento, residindo no espaço com sua família. Apesar de ser aberto e sensível a toda ajuda possível, o aposentado tem muita discrição em relação às atividades desenvolvidas no espaço. Ele procura evitar tensões com a empresa concessionária, uma vez que o imóvel, formalmente, permanece como propriedade da Rumo Logística, dinamizando a pauta do movimento pela regularização do espaço e buscando a parceria de moradores, artistas, pesquisadores e políticos, com intuito de promover o Ferrinho, enquanto aparelho cultural aberto ao público de Porto Alegre. No final de setembro de 2016, no Grêmio Esportivo Ferrinho, ele comemorava, exibindo, orgulhosamente, a certidão de tombamento do espaço, concedida pelo governo do município de Porto Alegre em julho de 2016.

Hélio Bueno, enquanto militante da memória ferroviária, também estava engajado ao projeto cultural "A tecnologia resgatando a memória ferroviária do Rio Grande do Sul”, na interlocução com Moises Porto (maquinista) e Ricardo Reischak (agente de estações). A iniciativa, financiada pelo Fundo de Apoio à Cultura (FAC), vinculado à Secretaria Estadual de Cultura do Rio Grande do Sul (SEDAC) em 2015, oportunizou a emergência e o compartilhamento de perspectivas singulares sobre a história ferroviária, que puderam ser narradas em vídeos pelos ferroviários convidados. Entre os propósitos do projeto, estava a composição de vídeos-crônicas temáticos, acervados para consulta em um "totem multimídias", também disponível como aplicativo de celular (Figura 5D). A plataforma digital interativa reúne vídeos, fotografias, mapas e informações das estações e ramais férreos do Rio Grande do Sul. Logo, os objetivos de contribuir para a experiência de visitação ao Museu do Trem resultaram em um instrumento tecnológico de restituição das imagens de nossas pesquisas. 


\section{CONCLUSÕES}

Neste texto, buscamos demonstrar a força da convergência de imagens e dos materiais etnográficos, enfatizando a importância da escrita coletiva. Essa foi a forma de creditarmos um trajeto de aprendizados em uma ciência que é, por pressuposto teórico e metodológico, dialógica. Não há aprendizado sem trocas e sem interlocuções, no amplo sentido do termo.

Essa justificativa se afirma na filiação à etnografia da duração (Rocha \& Eckert 2013), no caráter dos objetos de pesquisa e na forma como compreendemos o fenômeno da memória coletiva nas cidades contemporâneas e estruturamos metodologicamente nossas interpretações sobre ela.

[...] pensar o fenômeno da memória coletiva pela elaboração e geração de coleções etnográficas de conjuntos documentais de imagens pelo encadeamento de símbolos e das motivações simbólicas que as orientam torna evidente que este ato de pesquisa não pode ser uma obra sistemática de um só pensador, uma vez que a pesquisa com a etnografia da duração integra, ela própria, o patrimônio da humanidade (Rocha \& Eckert 2013:64).

Esforçamo-nos em operar eticamente com as imagens e as narrativas "dos outros", produzindo nossas próprias histórias a serem narradas, nunca descoladas das experiências de campo. Assim, nossas chaves interpretativas estiveram organizadas em constelações de imagens, regidas por categorias que nos foram caras, como as de crise, duração, patrimônio, projeto, ruína, cidade e trabalho. Ambas as constelações procuram situar os engajamentos da comunidade ferroviária do estado do Rio Grande do Sul a favor da permanência de sua memória coletiva sobre um tempo descontínuo. Quisemos, com as constelações imagéticas, acompanhar os regimes de imagens da crise e da duração ferroviária no Sul do Brasil, apontando para nosso engajamento, enquanto comunidade antropológica, nos projetos de duração das populações das urbes contemporâneas.

Destacamos, ainda, o diálogo com o campo da etnografia do e no mundo do trabalho, em contexto de envelhecimento, aposentadoria e crise profissional. Ao centrarmos a abordagem nos "desejos de memória", acompanhamos uma comunidade de trabalhadores fora dos espaços e dos tempos que seriam mais comuns. Não estamos falando de trabalhadores na fábrica ou "na lida". Também não estamos falando de aposentados resignados ao abandono ou à depressão, por conta da "inutilidade" em uma sociedade cada vez mais produtivista.

A valorização dos narradores ferroviários fez com que acompanhássemos alguns dos projetos de memória dos grupos, transpondo a etnografia para contextos que eram, em princípio, inusitados, mas que foram se afirmando cada vez mais como importantes ao longo dos trajetos de pesquisa e de alianças. Os museus, as palestras, as falas públicas, os programas de rádio e de televisão, as atividades universitárias, os eventos acadêmicos e os grupos no Facebook transformaram-se em 
"lugares antropológicos" fundamentais para a compreensão da complexidade da duração e da memória coletiva do trabalho e das cidades contemporâneas. Em todos esses contextos, as imagens da memória ferroviária vibraram, acompanhando as narrativas comprometidas e a militância cultural e patrimonial dos ferroviários(as) aposentados(as) e de suas famílias.

\section{REFERÊNCIAS}

Amorelli, L. C. 2003. Cultura organizacional e relações de poder: mapeando a Rede Ferroviária Federal S.A., em liquidação. Dissertação de Mestrado, Departamento de Gestão Empresarial, Fundação Getúlio Vargas.

Bachelard, G. 1988. A dialética da duração. São Paulo: Ática.

Bachelard, G. 2010. A intuição do instante. Tradução Antonio de P. Danesi. 2. ed. Campinas: Verus.

Benjamin, W. 1989. Sobre alguns temas em Baudelaire, in Walter Benjamin obras escolhidas III. São Paulo: Brasiliense.

Benvenuti, A., L. M. Pizzato, e Y. S. Rapkiewicz. 2013. Ação educativa: uma experiência inclusiva no Museu do Trem. in I Salão Científico Cultural MARS Santander Cultural: patrimônio cultural e museus. Organização de Márcia Bertotto e Walmir Pereira, pp. 145-158. Porto Alegre: Museu da UFRGS/PROREXT.
BIEV UFRGS. 2018. Banco de Imagens e Efeitos Visuais. Disponível em: https://www.ufrgs.br/ biev/. Acesso em: 28 abr. 2019.

Braz, C., C. Eckert,D. Dubiela, F. Barreto, F. S. Rodrigues, G. Gómez, J. Calixto, J. L. Abalos Junior, M. Baldissera, M. Bordin, N. Rigon, R.Simon, R. Kubo, Y.S. Rapkiewicz, D. Wobeto, L. Palhano, L. Dantas, e T. Tavares Freitas. 2018. Etnografia de rua e arte urbana em Porto Alegre (RS, Brasil). Vista (3):217-236. Disponível em: http:// vista.sopcom.pt/ficheiros/20190128-navisual.pdf. Acesso em: 28 abr. 2019.

Calloni, H. 2010. Nos trilhos da história da ferrovia: entrevista com Paulo Nilton de Carvalho. Rio Grande: Editora da FURG.

Certeau, M. 1994. A invenção do cotidiano: artes de fazer. v. 1. Rio de Janeiro: Petrópolis.

Cioccari, M. 2015. Ecos do subterrâneo: cotidiano e memória em uma comunidade de mineiros de carvão. Rio de Janeiro: Ventura.

Devos, R. 2005. Etnografia visual e narrativa oral: da fabricação à descoberta da imagem. Iluminuras 6(14):1-20.

Durand, G. 2002. As estruturas antropológicas do imaginário. 3a. ed. São Paulo: Martins Fontes. 
Eckert, C. 2012. Memória e trabalho: etnografia da duração de uma comunidade de mineiros do carvão (La Grand-Combe, França). Curitiba: Appris.

Estivalet, Í. R., e Y. S. Rapkiewicz. 2017. Audiovisualidade e museu: relatos de ferroviários do rio grande do sul. Anais Eletrônicos do Encontro História, Imagem e Cultura Visual - ANPUH-RS 4:298-308.

Ferraz, A. L. 2009a. Dramaturgias da autonomia: a pesquisa etnográfica entre grupos de trabalhadores. São Paulo: Perspectiva.

Ferraz, A. L. 2009b. 'No decorrer da luta, você vai se descobrindo': experiências com o vídeo etnográfico na representação de processos sociais. Revista Anthropológicas 20(1-2):81-96.

Flôres, J. R. A. 2007. Fragmentos da história ferroviária brasileira: fontes documentais, principais ferrovias, Viação Férrea do Rio Grande do Sul (VFRGS), Santa Maria, a "cidade ferroviária". Santa Maria: Palloti.

Geertz, C. 2014. A interpretação das culturas. Rio de Janeiro: LTC.

Gómez, G. S. R., e Y. S. Rapkiewicz. 2017. Rumores ferroviários e seus jogos temporais: estudo antropológico sobre crise e duração no Rio Grande do Sul. Trabalho Apresentado no $41^{\circ}$ Encontro Anual da ANPOCS, no SPG 04 - Antropologia e Sociologia dos Rumores. Disponível em: https://www.anpocs.com/ index.php/papers-40-encontro-2/spg-4/spg044/10944-rumores-ferroviarios-e-seus-jogostemporais-estudo-antropologico-sobre-crisee-duracao-no-rio-grande-do-sul/file. Acesso em: 28 abr. 2019.

Gómez, G. S. R. 2018a. Etnografia da crise e da duração ferroviária em Pelotas: um estudo antropológico de memória coletiva. $238 \mathrm{f}$. Dissertação (Mestrado) - Departamento de Antropologia Social, Universidade Federal do Rio Grande do Sul. Disponível em: https://lume.ufrgs. br/handle/10183/179424. Acesso em: 28 abr. 2019.

Gómez, G. S. R. 2018b. Imagens do verde e da ferrugem: crise e duração do trabalho ferroviário sul-brasileiro. Revista Fotocronografias 3(6). Disponível em: https://medium.com/ fotocronografias/imagens-do-verde-e-daferrugem-crise-e-dura\%C3\%A7\%C3\%A3o-dotrabalho-ferrovi\%C3\%A1rio-sul-brasileiroccbb1fec8b76. Acesso em: 28 abr. 2019.

Halbwachs, M. 2006. A memória coletiva. São Paulo: Centauro.

Hannerz, U. 2015. Explorando a cidade: em busca de uma antropologia urbana. Petrópolis: Vozes. 
Harres, M. M. 1996. Disciplina e trabalho: administração de iniciativa na VFRGS. Estudos Ibero-Americanos 22(2):111-127.

Heinen, N. T. 1981. Introdução ao estudo das ferrovias no Rio Grande do Sul: 18741905. Trabalho de Conclusão de Curso, Departamento de História, Universidade Federal do Rio Grande do Sul.

Hobsbawm, E. 1977. A era do capital 1848-1875. Rio de Janeiro: Paz e Terra.

Leite Lopes, J. S. 1978. O vapor do diabo: o trabalho dos operários de açúcar. Rio de Janeiro: Paz e Terra.

Lewinski, C. I. K. 2017. Um lugar de memória da estrada de ferro: o centro de preservação da história ferroviária do Rio Grande do Sul. Dissertação de Mestrado, Departamento de História, Unisinos.

Lima Filho, M. F. 2015. Cidadania patrimonial. Revista Anthropológicas 26(2):134-155.

Lord, L. 2002. Nascidos na beira do trilho: um estudo antropológico na Vila dos Ferroviários/Porto Alegre. Iluminuras $3(5): 1-75$.
Magnani, J. G. C. 2002. De perto e de dentro: notas para uma etnografia urbana. Revista Brasileira de Ciências Sociais 17(49):11-29.

Magnani, J. G. C. 2012. Da periferia ao centro: trajetórias de pesquisa em antropologia urbana. São Paulo: Terceiro Nome.

Magni, C. T., e G. S. R. Gómez. 2017. "Vida nos trilhos": desafios de um projeto participativo para ensino, pesquisa e extensão em Antropologia Visual. Anais do $41^{\circ}$ Encontro da ANPOCS. Disponível em: http:// www.anpocs.com/index.php/papers-40-encontro-2/ gt-30/gt14-22/10729-vida-nos-trilhos-desafios-de-umprojeto-participativo-para-ensino-pesquisa-e-extensaoem-antropologia-visual/file. Acesso em: 28 abr. 2019.

Marcus, G. 2016. Problemas contemporâneos da etnografia no sistema mundial moderno, in $A$ escrita da cultura: poética e política da etnografia. Organizado por J. Clifford \& G. Marcus, pp. 237270. Rio de Janeiro: Papéis Selvagens.

Nunes, I. 2016. Expansão e crise das ferrovias brasileiras nas primeiras décadas do século XX. América Latina en la Historia Económica 23(3):204-235.

Nunes, R. B. 2013. A boca, a esquina e o recanto: territórios urbanos e memória coletiva no centro de Santa Maria, RS. Santa Maria: Pallotti. 
Ortner, S. B. 2016. Dark anthropology and its others theory since the eighties. Hau - Journal of Ethnographic Theory 6(1):47-73.

Palermo, H. 2012. Cadenas de oro negro: en el esplendor y ocaso de YPF. Buenos Aires: Antropofagia.

Paradela, C. L. 1998. Desestatização da rede ferroviária federal S/A. Impactos sobre os recursos humanos da administração geral. Dissertação de Mestrado, Departamento em Administração Pública, Fundação Getúlio Vargas.

Pereira, A. P. 2017. Sonoridades do trem na cidade de Pelotas-RS: percepções e significados. Dissertação de Mestrado, Departamento de Antropologia Social, Universidade Federal de Pelotas.

Rapkiewicz, Y. S., e C. Eckert. 2015. Entre trilhos e temporalidades: o tempo do trabalho nas memórias dos ferroviários aposentados de Porto Alegre. in Etnografias do trabalho: narrativas do tempo. Organizado por C. Eckert e A. L. C. Rocha, pp. 276-303. Porto Alegre: Marcavisual.

Rapkiewicz, Y. S., e G. S. R. Gómez. 2016. Vestígios, ruínas e os sentinelas da memória ferroviária do Rio Grande do Sul: ensaio etnofotográfico nas cidades de Pelotas e Porto Alegre. Nova Revista Amazônica 4(3):82-94. Disponível em: https://drive.google.
com/file/d/0BwCIcth2qyvMR01aVmxGMjBjNDA/ view. Acesso em: 28 abr. 2019.

Rapkiewicz, Y.S., eL.J. Abalos Junior. 2017. Imaginário e restituição no colecionamento etnográfico: convergências de imagens e patrimônios de Porto Alegre - RS. Trabalho apresentado no $41^{\circ}$ Encontro Anual da ANPOCS, no GT 04-Coleções, colecionadores e práticas de representação. Disponível em: https:// www.anpocs.com/index.php/papers-40-encontro-2/ gt-30/gt04-20/10627-imaginario-e-restituicao-nocolecionamento-etnografico-convergencias-deimagens-e-patrimonios-em-porto-alegre-rs/file. Acesso em: 28 abr. 2019.

Rapkiewicz, Y. S. 2018. Cidades, patrimônios e etnocolecionadores: uma etnografia das reminiscências ferroviárias no Sul do Brasil. Dissertação de Mestrado, Departamento de Antropologia Social, Universidade Federal do Rio Grande do Sul. Disponível em: https://hdl. handle.net/10183/182798. Acesso em: 28 abr. 2019.

Ricoeur, P. 1991. A questão da ipseidade, in $O$ simesmo como um outro. Editado por P. Ricoeur, pp. 11-28. Campinas: Papirus.

Rocha, A. L. C., e C. Eckert. 2000. Imagens do tempo nos meandros da memória: por uma etnografia da duração. Iluminuras 1(1):2-14. 
Rocha, A. L. C., e C. Eckert. 2005. O antropólogo na figura do narrador, in O tempo e a cidade. Editado por A. L. C. Rocha e C. Eckert, pp. 21-33. Porto Alegre:UFRGS.

Rocha, A. L. C., e C. Eckert. 2013. Etnografia da duração: antropologia das memórias coletivas em coleções etnográficas. Porto Alegre: Marcavisual.

Rocha, A. L. C., e C. Eckert. 2015a. A preeminência da imagem e do imaginário nos jogos da memória coletiva em coleções etnográficas. Brasília: ABA.

Rocha, A. L. C., e C. Eckert. 2015b. Etnografias do trabalho: narrativas do tempo. Porto Alegre: Marcavisual.
Sennett, R. 2015. A cultura do novo capitalismo. Rio de Janeiro: Record.

Silva Junior, R. 2007. O transporte ferroviário de cargas no Brasil e na Argentina: da implantação à recente privatização. Revista de Economia Política e História Econômica (7):5-38.

Simões, J. A. 2004. Provedores e militantes: imagens de homens aposentados na família e na vida pública, in Família e envelhecimento. Organizado por C. Peixoto, pp. 25-56. Rio de Janeiro: FGV. 